\title{
Development of Nation State of Malaysia Based on Mahathir Mohamad's Leadership Model Framework
}

\author{
Khairul Azman Mohamad Suhaimy ${ }^{a}$, Nurul Aimi Razalib ${ }^{b}$ Lutfan Jaes $^{c}$ and dan Muhamad Helmy Sabtu \\ a,b,c,d \\ Centre for General Studies and Co-Curricular, Universiti Tun Hussein Onn Malaysia
}

Article History: Received: 11 January 2021; Accepted: 27 February 2021; Published online: 5 April 2021

\begin{abstract}
Each Prime Minister has his or her own leadership and achievements while leading the development of the nationstate. Mahathir Mohamad's leadership and achievements in driving Malaysia's modernization are well known because the effort has succeeded in benefiting Malaysians so that he can be appointed as the Father of Malaysian Modernization. The effectiveness of his leadership can be assessed based on the achievements that have been successfully achieved by the country through the implementation of actions and policies that he led throughout leading the country. Therefore, this article aims to discuss the elements of Mahathir's leadership by tracing his leadership when implementing actions and policies to modernize Malaysia so that it can achieve a proud achievement in the context of the development of the Malaysian nation. This study uses the method of document analysis by analyzing the text of Mahathir's speech as the main source and applying thematic analysis as an analysis approach. The text of the speech was analyzed thematically to identify the themes that exist and refer to the elements of leadership applied by him throughout the implementation of actions and policies to modernize the country. The results of the analysis show that there are 11 elements of leadership practiced by Mahathir such as injecting intellectual, injecting motivation, practicing good values in governing, valuing togetherness, exhibiting ideal influence, organized in leadership, assertive in leading, far-sighted, considerate of each individual, appreciating the contribution of the people, and confident in the ability to lead. Indirectly, the results of the analysis reflect that a country can achieve a proud achievement in the process of modernization if the country's leaders practice certain elements of leadership. The implications of this study, first, reflect the importance of a leader's leadership evaluation based on the achievements that have been achieved because it can identify a set of leadership elements practiced by the leader. Second, it reflects the importance of the role of leaders in determining and shaping the definition of nation-state development that should be highlighted in a country. The contribution of this study is to introduce a leadership model framework based on Mahathir's achievements throughout his administration of the Malaysian nation. In addition, it gives an overview of the elements of his leadership as a successful national leader. This leadership model framework is also suitable to be applied by leaders or related parties involved or interested in leadership-related discussions.
\end{abstract}

Keywords: Mahathir Mohamad, leadership model framework, development, nation state

\section{Introduction}

Mahathir Mohamad is a Prime Minister of Malaysia who is known for his leadership and achievements in modernizing Malaysia in his own way. He was a firm and vocal person but meticulous in leading and governing the country towards modernization. Although there are some who doubted the actions and policies that he pioneered, those actions and policies have succeeded in becoming the basis of modernization of the country that can be utilized by Malaysians (Omar \& Pandian, 2006). This situation refers to the available facilities and the benefits that can be enjoyed by all Malaysians today.

In taking steps towards modernization, Mahathir has successfully implemented actions and policies that provide employment opportunities and strengthen the country's industry, and he has even successfully launched human capital development oriented policies (Omar \& Pandian, 2006; Welsh, 2005). This is in line with his belief that the civilization of a country is more comprehensive and perfect through the development of physical infrastructure with the emphasis on the development of the people as human capital to the country. Both of these elements are important in the development of a country because they complement each other (Jaes, 2017; Mohamad \& Ibrahim, 1994; Suhaimy, 2009). Therefore, the economic, political and social sectors of a country are very important to be processed simultaneously by prioritizing these two elements. Mahathir has proven his ability in leading this effort based on the emphasis on the development of physical infrastructure as well as the development of the people in modernizing Malaysia.

\section{Literature Review}

\subsection{Development of Nation State}

The concept of nation-state has existed since the 15th century following the emergence of the modern system of nations also known as the Westphalia System. This system was created as a result of the Treaty of Westphalia 1648 which was sealed due to the search for an end to the Thirty Years' War involving Catholics and Protestants in the Holy Roman Empire, Germany, which has led to religious divisions across Europe (Osborne, 2018). 
In practice, the Westphalia System does not create a nation state but the concept and elements of the establishment of a nation state are in line with the essence and criteria of the system. The criteria of this system assume that every country has sovereignty over areas and internal affairs, without requiring the involvement of external powers, whether large or small, this is subject to international law (Jonas \& Wilson, 2018).

The concept of nation-state as the basis for the establishment of a nation is fundamental because it allows a uniform national culture to be formed through national policy. The concept assumes that the people residing in a country are united by the same lineage, language and culture. Abdul Rahman Embong (2001) defined nation state operationally as "a state that combines political entities with the cultural entities of a nation, aimed at legitimizing political legitimacy to govern and elevate the status of the nation as sovereign".

Ahmad Fawzi Basri (1987) and Mohammad Redzuan Othman (2006) stated that the nation state exists in modern times when a population of various ethnicities, cultures, and religions live in the same area. This shows that there are three main components that make up the establishment of a nation state, namely individuals, races, and nations. Individuals are fundamental to the creation of a race and a nation because every interaction that takes place will affect the relationship between individuals and then, create a group that has the same characteristics and interests, and in turn, will form a race with its own administrative direction and create a nation. A race is a union that exists between individuals residing in a nation. Race also refers to a large group in which members have similar beliefs and follow a specific identity that assumes a group of individuals who have similar characteristics through genealogical, historical and cultural ties. Meanwhile, a nation is a political unit that has the responsibility, power, sovereignty, and independent of others in implementing the administrative agenda.

Abdul Rahman Embong (2001) also argues that a country should have components such as sovereignty, people, territory and legitimate government. In addition to the combination of these four components, a nation-state must have other characteristics such as a multiracial society, living in harmony, respecting the beliefs of different political ideologies, and having faith and confidence in the nation's administrative system, and the constitution and laws of the nation. In addition, consolidation factors such as integration, patriotism, nationalism, and democracy are able to strengthen the establishment of a nation state. In the context of the Malaysian nation-state, the formation of the race occurs uniquely due to the historical, political, economic, and social interactions of the nation that make up the Malaysian Nation" (Shamsul Amri Baharuddin, 1990; Abdul Rahman Embong, 2001; Mohammad Redzuan Othman, 2006). Thus, Bangsa Malaysia are individuals who originate or reside in Malaysia, share a region, economy, culture, and have the same future fate, and appearance of the nation. In the context of this article, the development of the nation-state of Malaysia refers to the process of development of Malaysia as a nation comprising all people of various races.

\subsection{Mahathir Mohamad}

Mahathir Mohamad is the only Prime Minister of Malaysia to serve for the longest time and twice, as the fourth and seventh Prime Minister of Malaysia. He led the administration of the country as the fourth Prime Minister from June 28, 1981 until October 31, 2003 for 22 years, while as the seventh Prime Minister from May 10, 2018 until March 1, 2020 (Abdullah, 2019; Ong, 2005). The significance of his leadership and contribution is undeniable although there are some who consider him a dictator because of his autocratic style of leadership (Cheah \& Ahmad, 2017a; Omar \& Pandian, 2006; Ong, 2005; Suppiah \& Gunasekaran, 2018). His leadership played an important and beneficial role in the modernization of the country. While serving as the fourth Prime Minister, Mahathir has implemented various actions and policies that have resulted in Malaysia successfully experiencing sustainable development and advanced modernization until Malaysians elevate him as the Father of Modernization (Cheah \& Ahmad, 2017a; Omar \& Pandian, 2006; Suppiah \& Gunasekaran, 2018).

Mahathir was actively involved in trying to change the fate of the people and the country as early as he was a teenager. He was aware of issues that inhibit the progress of the Malays in Malaya when he was young. He has a high fighting spirit and aspirations to help the Malays to be more advanced in the field of education, economy and technology without neglecting the opportunities and rights of other races (Omar \& Pandian, 2006; Ong, 2005). In addition to his contribution to the issue of the development of the youths at a young age, his leadership and contribution became more significant during his tenure at the central government level because the action was in the form of policy; to be implemented on all Malaysians. Among his significant actions and policies is the reformation of the National Education Policy which aims to eradicate poverty and provide justice to all multiracial citizens through education as well as the amendment of the Universities and Colleges Act 1974 which aims to place university administration under the Ministry of Education to be more controlled and regulated when he became the Minister of Education in 1974 (Ibrahim, 2007; Sundaram \& Cheek, 1988).

Mahathir's leadership and contribution to the modernization of the Malaysian nation-state was more comprehensive when he became the Prime Minister. Various national policies, mega projects and the country's advanced direction with the nature of developing the Malaysia nation have been successfully implemented. The initiatives taken are fundamental because most of the initiatives are in the form of programs that change the pattern of thinking, living culture, work ethic, strengthening education and also the economic empowerment of the people (Cheah \& Ahmad, 2017a; Omar \& Pandian, 2006; Ong, 2005; Suppiah \& Gunasekaran, 2018 ). The initiatives 
launched are beneficial to the people because they succeed in shaping the people to be more competitive in preparation for the globalization process. Among the initiatives he pioneered were the strengthening of the civil service and the administration of the country through standardization of systems and working methods involving the use of time card system, introduction of name tag, file storage system, correspondence and postal affairs, guidance and coordination in every office business through collaboration with top civil servants (Hussain, 1997; Rohman \& Sabri, 2017). These strengthening initiatives are further strengthened with initiatives such as the application of good values and the practice of good work ethic through the launch of programs and policies such as Clean, Efficient and Trust Campaign, Leadership by Example, Application of Islamic Values, and Look East Policy (Furuoka, 2007; Rohman \& Sabri, 2017). Although the main focus of these initiatives is to strengthen the work ethic of civil servants and national leaders at the civil service and national administration levels, this initiative has also affected the thinking pattern and life culture of Malaysians in becoming better as they emulate the example shown by civil servants and leaders; as small government ambassadors to them (Rohman \& Sabri, 2017). In addition, Mahathir's contribution to the modernization of the country can also be seen based on the launch of the Malaysian Incorporated Policy which aims to build a cooperation between the government and the private sector in creating a corporate-based country where profits will be shared jointly between the two sectors for the economic empowerment of the country (Wiliamson, 2002). This policy has succeeded in bringing Malaysia to a higher level as the country's economy has been successfully enhanced and strengthened from year to year since its launch.

In addition, Mahathir's contribution to the country can also be proven through his success in preventing the country from being badly affected by the Asian Financial Crisis 1997-1998. He has pegged the Malaysian ringgit to the US Dollar at a fixed price of RM 3.80 for every 1 US Dollar (Haggard, 2000). This contribution has proven the credibility of his leadership as it contributes to the long-term sustainability of the country's economy by preventing the country from continuously facing a deteriorating economic downturn and getting involved in a debilitating debt crisis. Other contributions made by Mahathir have been to launch Vision 2020 which aims to be a cornerstone and guide to achieving the goals of a developed and systematic country in political, economic and social aspects, including infrastructure, science and technology by 2020 (Khattab, 2004; Nathan, 1995). In addition, Mahathir has also pioneered mega projects such as the construction of administrative centre in Putrajaya, Kuala Lumpur City Center (KLCC), skyscrapers Kuala Lumpur Tower and Petronas Twin Towers, Kuala Lumpur International Airport (KLIA), Formula One Sepang Circuit and Multimedia Super Corridor (MSC), in order to achieve this vision (Bunnell, Barter \& Morshidi, 2002; Beng, 2006; Embong, Hassan, \& Ibrahim, 2016; Jackson \& Mosco, 1999; Taylor, 2003). As a developing country, the idea of the vision and mega projects implemented by Mahathir is futuristic and high standard because those ideas are not a norm of a developing country.

Although Vision 2020 is not achieved as a whole due to some changes in the political and administrative landscape of the country, the benefits of the mega projects can clearly be enjoyed by Malaysians (Raj, Wahab, Osman, Zawawi \& Fazal, 2018). Therefore, it is undeniable that these vision and mega projects have succeeded in modernizing Malaysia which has the status of a third-world country. This proud achievement has lifted Mahathir's credibility as Prime Minister and placed him in a distinct statesman league. The legitimacy of his leadership proved to be acknowledged by the people when he was given the mandate to be the seventh Prime Minister after Pakatan Harapan (PH) won the 14th general election (Abdullah, 2019). Mahathir's leadership during both administration periods showed different but positive dynamics with each other. These differences take into account the differences in the time period and the current situation of the government that governed the country at that time. However, this article focuses on the discussion on Mahathir's leadership when he was the fourth Prime Minister, as the Father of Modernization.

\section{Methodology}

This study applied a qualitative approach. According to Glass and Hopkins (1984) as well as Danto (2008), this approach allows a situation or social event that has occurred to be interpreted well. This approach can also show patterns or remove themes that exist from a situation (Mcdowell, 2013). Meanwhile, the method used to support this approach is the analysis document. This method is in line with the objective of the study which aims to study the elements of leadership practiced by Mahathir while driving the modernization of the nation-state as the fourth Prime Minister based on the speech texts as the main source. The speech texts were analysed qualitatively using thematic analysis to explore the themes that refer to the elements of leadership that he practiced. The speech texts analysed were the New Year and Independence Day celebration speeches. Both types of speech texts are chosen because the audience to these speech texts is all Malaysians. The leadership elements identified are then conceptualized in the form of a leadership model framework.

Table 1 shows that there are eight speech texts that have been delivered by Mahathir including the texts of the New Year celebration and Independence Day speeches from 1982 to 1986. The initial five years of administration were applied for the implementation of this study. The period was chosen because it is an important period for a leader and the government they led to introduce and strengthen the administrative and development action plans of a country. Because Mahathir was in the administration of the country starting June, 1981, it means that the New Year celebration for that year had passed, while the speech text for the celebration of Independence Day that year could not be found. In addition to the efforts to obtain all relevant speech texts for the period, in total, there were 
three related speech texts that could not be entered because they were not successfully obtained. Due to this limitation, the five-year period was taken from 1982 to 1986.

Table 1. Mahathir Mohamad's Speech Texts

\begin{tabular}{ccc}
\hline Year & Text & Text Code \\
\hline 1982 & Independence Day celebration & S1 \\
1983 & New Year celebration & S2 \\
& Independence Day celebration & S3 \\
1984 & New Year celebration & S4 \\
& Independence Day celebration & S5 \\
1985 & New Year celebration & S6 \\
& Independence Day celebration & S7 \\
1986 & New Year celebration & S8 \\
\hline
\end{tabular}

\section{Findings of the Study}

\subsection{Mahathir's Leadership Elements}

The results of this study have shown that Mahathir has highlighted the element of achievement-oriented leadership in leading the development of the Malaysian nation-state. These 11 elements of leadership are injecting intellectual, injecting motivation, practicing good values in governing, valuing togetherness, exhibiting ideal influence, organized in leadership, assertive in leading, far-sighted, considerate of each individual, appreciating the contribution of the people, and confident in the ability to lead.

Table 2. Mahathir Mohammad's Leadership Elements

\begin{tabular}{|c|c|c|c|c|c|c|c|c|c|c|c|}
\hline $\begin{array}{l}\text { Text } \\
\text { Code }\end{array}$ & $\begin{array}{c}\text { Organized In } \\
\text { Leadership }\end{array}$ & $\begin{array}{c}\text { Assertive } \\
\text { In } \\
\text { Leading }\end{array}$ & $\begin{array}{c}\text { Confident In } \\
\text { The Ability } \\
\text { To Lead } \\
\end{array}$ & $\begin{array}{c}\text { Far- } \\
\text { Sighted }\end{array}$ & $\begin{array}{c}\text { Exhibiting } \\
\text { Ideal } \\
\text { Influence }\end{array}$ & $\begin{array}{c}\text { Valuing } \\
\text { Togetherness }\end{array}$ & $\begin{array}{c}\text { Injecting } \\
\text { Intellectual }\end{array}$ & $\begin{array}{c}\text { Injecting } \\
\text { Motivation }\end{array}$ & $\begin{array}{c}\text { Considerate } \\
\text { Of Each } \\
\text { Individual } \\
\end{array}$ & $\begin{array}{c}\text { Appreciating The } \\
\text { Contribution of } \\
\text { The People }\end{array}$ & $\begin{array}{c}\text { Practicing } \\
\text { Good Values } \\
\text { In Governing } \\
\end{array}$ \\
\hline S1 & 5 & 5 & 2 & 0 & 3 & 5 & 18 & 7 & 0 & 1 & 3 \\
\hline S2 & 5 & 0 & 0 & 1 & 6 & 8 & 12 & 7 & 4 & 0 & 6 \\
\hline S3 & 1 & 2 & 0 & 2 & 0 & 8 & 7 & 4 & 0 & 0 & 1 \\
\hline S4 & 3 & 0 & 0 & 2 & 3 & 3 & 7 & 5 & 0 & 2 & 5 \\
\hline S5 & 2 & 0 & 0 & 2 & 7 & 0 & 16 & 5 & 0 & 0 & 7 \\
\hline S6 & 4 & 4 & 0 & 2 & 2 & 4 & 11 & 4 & 0 & 0 & 8 \\
\hline S7 & 2 & 3 & 0 & 1 & 2 & 0 & 13 & 4 & 0 & 1 & 3 \\
\hline S8 & 3 & 6 & 1 & 0 & 4 & 1 & 16 & 7 & 1 & 0 & 5 \\
\hline Total & 25 & 20 & 3 & 10 & 27 & 29 & 100 & 43 & 5 & 4 & 38 \\
\hline
\end{tabular}

Table 2 shows that the most common element of leadership applied by Mahathir is to inject intellectuals with a frequency of 100 based on the analysed speeches. Followed by the elements of injecting motivation and practicing good values in governing with a frequency of 43 and 38, respectively. Other elements of leadership applied by Mahathir in moderation are the valuing togetherness and exhibiting the ideal influence with a frequency of 29 and 27, respectively. Next, the elements of leadership that he practiced with a low frequency are considerate of each individual, appreciating the contribution of the people, and be confident in the ability to lead. Therefore, it can be concluded that dominantly, Mahathir's leadership is oriented towards the elements of injecting intellectual, injecting motivation, and practicing noble values in governing.

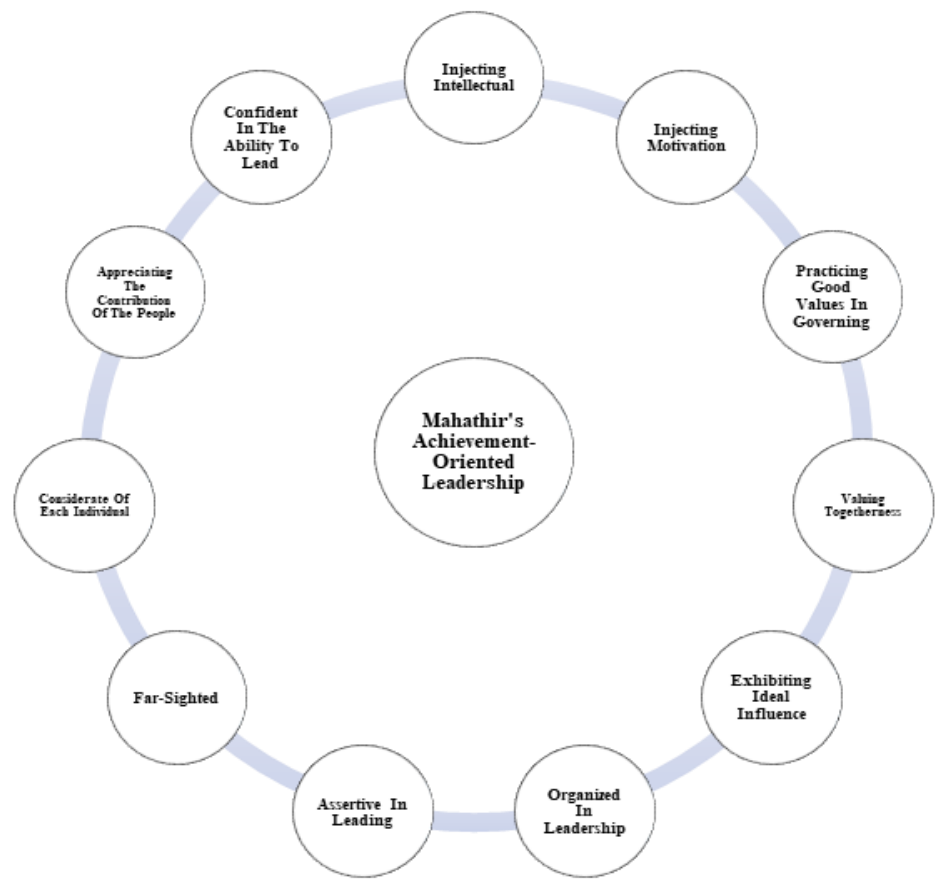

Figure 1. Mahathir Mohamad Achievement-Oriented Leadership Model Framework in the Nation State Development Context 


\section{Discussion}

Based on the thematic analysis carried out on eight speech texts delivered by Mahathir in conjunction with the New Year and National Day celebrations, there were 11 elements of leadership have been identified with a total frequency of 304 which have been exhibited by Mahathir throughout driving modernization of Malaysia. The results of the analysis show that the elements of leadership that he exhibited were injecting intellectuals, injecting motivation, practicing good values in governing, valuing togetherness, exhibiting ideal influence, organized in leadership, assertive in leading, far-sighted, considerate of each individual, appreciating the contribution of the people, and confident in the ability to lead, in descending order. Figure 1 is the framework of Mahathir's achievement-oriented leadership model in the context of nation-state development.

In leading the country's leadership, Mahathir dominated his leadership with elements of intellectual injection, injecting motivation, and practicing good values in governing. Mahathir's leadership emphasized the element of intellectual injection because it can give them an understanding of the reason and purpose of a matter should be carried out, and then encouraged them to implement relevant follow-up actions to achieve that goal (Abdullah, 2019; Cheah, Yusof \& Ahmad, 2017b; Suppiah, Ahmad, \& Gunasekaran, 2018). The situation of Malaysians during Mahathir's administration at that time was also important to consider in discussing the elements of leadership applied by him. This is because the current situation of the people is one of the reasons why a leader practices certain elements of leadership.

Following the elements of injecting intellectual and injecting motivation in leadership, organized in leadership is also important and necessary because the people need clear guidance on how a goal is to be achieved such as actions that should be taken to realize a goal (Lovelace, Neely, Allen \& Hunter, 2019; McCleskey, 2014).

During the first five years Mahathir's leadership in Malaysia from 1981 until 1986, Malaysians had experienced independence for 24 years. Relatively, although still new, the people were aware of the development processes that had been carried out by the three previous Prime Ministers, namely Abdul Rahman Putra, Razak Hussein, and Hussein Onn. However, the people were still new to the idea of developing the nation-state of Malaysia which aimed and led to the modernization process brought by Mahathir at that time. Therefore, with regard to the situation of the people who were still new to the idea of modernization, then the approach taken by Mahathir in leading Malaysians is appropriate. He emphasized the elements of injecting intellectuals and injecting motivation in leading the modernization of the country. People needed reason and rationale for the idea of modernization because it was something new and they were not familiar (McCleskey, 2014; Sendjaya, Pekerti, Härtel, Hirst \& Butarbutar 2016; van Houwelingen, van Dijke \& De Cremer, 2015). Mahathir successfully realized this need well because he often explained to the people about the rationale of an action taken or implemented by him or the government. He also did not hesitate to give examples and make comparisons with the situation of backwardness or progress that occurred around the world to Malaysians, so that they could understand the reason and rationale for an action taken by him or the government. For example, Mahathir explained why his government implemented democracy, but based on the local mould (Omar \& Pandian, 2006). To illustrate this, he gave an example of the practice of democracy in Western countries with no restrictions, where people can openly criticize the government and fight for human rights matters that they feel should be given attention blindly. This situation shows the openness of the people in fighting for human rights matters without limits until it leads to a moral collapse because there is no framework that drives the fight. Mahathir often gave the example by teaching why the practice of the same democracy is not practiced in Malaysia. This situation indirectly shows that Mahathir injected motivation to work together with the government in an effort to achieve modernization. The element of injecting motivation is also important for leaders to practice because it moves the people towards achieving the aspirations of the country they want together, in particular, once they know the reason and rationale why an idea is implemented.

Another element of leadership that also dominated Mahathir's leadership is the practice of good values in governing. Mahathir is well known for his perseverance in practicing good values in governing among Malaysians (Suhaimy, 2009; Jaes, 2017). The results of the analysis confirm that Mahathir was consistent in practicing good values in governing among Malaysians, especially at the beginning of his tenure. This is due to his desire that he often conveyed in most of his speeches which was the wish that Malaysians can adopt a positive life value system in life so that they can change and practice lifestyle and work ethic for the better and further, facilitate the mobilization and achievement of the national modernization agenda collectively.

Mahathir was also clear with the goal of modernizing Malaysia. He clearly fought for the formation of the Malaysian nation in Vision 2020 which was launched in 1991 because he knew the importance of the involvement of all Malaysians united for the lasting progress of Malaysia, especially in the era of globalization. Although there were some who say that the definition of the Malaysian nation in Vision 2020 was unclear, Mahathir still continued with his efforts to fight for the formation of the Malaysian nation which refers to the development of multiracial Malaysians as human capital who understand the essence of inter-racial unity for the common good and national progress. In realizing those efforts, he kept the privileges and rights of the Malays and Bumiputeras as the natives of Malaysia without neglecting the rights that should be received by Chinese, Indians, and others (Abdullah, 2019; Cheah, Yusof and Ahmad, 2017; Suppiah, Ahmad, \& Gunasekaran, 2018). Even so there are certain parties who calls him a Malay ultra-nationalist. But in reality, most Chinese and Indians accept and respect Mahathir's leadership because they understand the essence of the social contract that was agreed by their ancestors before the 
formation of the National Constitution. They understand the objective of the action or effort taken by Mahathir and his government. They are of the view that they are not marginalized by the Mahathir's government because all citizens have their rights and privileges fairly and equally in line with the matters enshrined in the National Constitution.

Therefore, Mahathir's dominant leadership elements, which refer to injecting intellectuals, injecting motivation, and practicing good values in governing, have succeeded in moving the agenda and goals of the development of a Malaysian nation-state, especially modernization. This matter is seen based on the achievements achieved by him during his tenure as the fourth Prime Minister. This successful achievement is due to his leadership which prioritized the involvement and togetherness of the people with the governing government in the effort to modernize the country. The close collaboration between the two parties, namely the people and the government, has succeeded in enabling Malaysia to achieve a world-class modernization under Mahathir's leadership.

\section{Conclusion}

This article has discussed in depth about the elements of Mahathir's achievement-oriented leadership in the context of the development of the Malaysian nation-state. Among the elements of leadership that have been identified as Mahathir's leadership elements are injecting intellectuals, injecting motivation, practicing good values in governing, valuing togetherness, exhibiting ideal influence, organized in leadership, assertive in leading, far-sighted, considerate of each individual, appreciating the contribution of the people, and confident in the ability to lead. The findings of this study are important because it highlights the importance of achievement-oriented leadership evaluation that can produce a certain set of leadership elements that are able to inject enthusiasm and mobilize the people to work together with the government in achieving the national development agenda and goals. Secondly, this study also shows the importance of the role of leaders in determining and shaping the definition of a nation state that should be created and elevated in a country.

Ultimately, Mahathir is a national leader who is meticulous and holistic in his approach to modernizing the nationstate of Malaysia through actions, policies, mega projects, and the idea of development and modernization of an advanced nation. Under his leadership, Malaysia has succeeded in reaching its own level of progress at a time when most other developing countries have not yet been able to achieve the same progress. This achievement shows the significance of Mahathir's leadership in the development of the Malaysian nation-state. Therefore, based on the achievements that Malaysia has achieved while under Mahathir's leadership, a set of achievement-oriented leadership elements has been formulated with reference to the leadership elements that he applied while driving the development and modernization of the country.

\section{Reference}

1. Abdullah, W. J. (2019). The Mahathir effect in Malaysia's 2018 election: the role of credible personalities in regime transitions. Democratization, 26(3), 521-536.

2. Arifin, F. M., \& Othman, N. (2018). The Dynamic of Policymaking Process in Malaysia. International Journal of West Asian Studies, 10(1).

3. Baharuddin, S. A. (1990). Masyarakat Malaysia yang membangun. Dewan Bahasa dan Pustaka, Kementerian Pendidikan Malaysia.

4. Basri, A. F. (1987). Isu-isu Perpaduan Nasional. Sintok, Kedah: Sekolah Pengajian Asasi UUM [Universiti Utara Malaysia].

5. Beng, O. K. (2006). Mahathir as Muslim leader. Southeast Asian Affairs, 2006(1), 172-180.

6. Bunnell, T., Barter, P. A., \& Morshidi, S. (2002). Kuala Lumpur metropolitan area: A globalizing cityregion. Cities, 19(5), 357-370.

7. Cheah, J. L. S., \& Ahmad, M. K. (2017a). Confucian Value-Based Leadership Communication: A study on Tun Dr. Mahathir Mohamad. Jurnal Komunikasi: Malaysian Journal of Communication, 33(3).

8. Cheah, J. L. S., Yusof, N., \& Ahmad, M. K. (2017b). Tun Dr. Mahathir's Leadership Communication: The Confucian Perspective. In SHS Web of Conferences (Vol. 33, p. 00060). EDP Sciences.

9. Chin, J. (2018). The Comeback Kid: Mahathir and the 2018 Malaysian General Elections. The Round Table, 107(4), 535-537.

10. Danto, E. A. (2008). Historical research. Oxford University Press.

11. Embong, A. E. (2001). Negara Bangsa: Proses dan Perbahasan [Nation state: Processes and debates]. Bangi: Penerbit UKM.

12. Embong, A. R., Hassan, H., \& Ibrahim, N. A. (2016). The representations of leadership by example in editorial cartoons. Malaysian Journal of Communication, 32(1), 625-650.

13. Haggard, S. (2000). The politics of the Asian financial crisis. Journal of Democracy, 11(2), 130-144.

14. Ibrahim, R. (2007). Multiculturalism and education in Malaysia. Culture and Religion, 8(2), 155-167.

15. Jackson, S., \& Mosco, V. (1999). The political economy of new: technological spaces: Malaysia's Multimedia Super Corridor. Journal of International Communication, 6(1), 22-40.

16. Jaes, L. (2017). Akal Budi Tempatan dalam Pengurusan Pembangunan Oleh Soeharto, Mahathir dan Lee Kuan Yew. Universiti Utara Malaysia: Ph.D. Thesis. 
17. Jomo, K. S. (2019). Southeast Asia's misunderstood miracle: industrial policy and economic development in Thailand, Malaysia and Indonesia. Routledge.

18. Jonas, A. E., \& Wilson, D. (2018). The nation-state and the city: Introduction to a debate. Urban Geography, 39(9), 1418-1420.

19. Khattab, U. (2004). Wawasan 2020: Engineering a Modern Malay (sia) State Campaigns and Minority Stakes. Media Asia, 31(3), 170-177.

20. Lovelace, J. B., Neely, B. H., Allen, J. B., \& Hunter, S. T. (2019). Charismatic, ideological, \& pragmatic (CIP) model of leadership: A critical review and agenda for future research. The Leadership Quarterly, 30(1), 96-110.

21. McCleskey, J. A. (2014). Situational, transformational, and transactional leadership and leadership development. Journal of Business Studies Quarterly, 5(4), 117.

22. Mcdowell, B. (2013). Historical research: A guide for writers of dissertations, theses, articles and books. Routledge.

23. Mohammad Redzuan Othman (2006). Sejarah pembinaan negara bangsa. UITM.

24. Morgan, G., \& Smircich, L. (1980). The case for qualitative research. Academy of management review, 5(4), 491-500.

25. Nathan, K. S. (1995). Vision 2020 and Malaysian foreign policy: Strategic Evolution and the Mahathir impact. Southeast Asian Affairs, 22, 220.

26. Osborne, T. (2018). Treaty of Westphalia/Peace of Münster (1648). The Encyclopedia of Diplomacy, 19.

27. Raj, P., Wahab, S. A., Osman, S. I. W., Zawawi, N. M., \& Fazal, S. A. (2018). Sustainable Development and Innovation: Reviewing the Concept and Malaysian Participation. International Journal of Academic Research in Business and Social Sciences, 8(9).

28. Rohman, M. A., \& Sabri, A. Z. S. A. (2017). Kempen "Kepimpinan melalui Teladan" semasa Era Pemerintahan Tun Dr. Mahathir Mohamad di Malaysia. Sains Humanika, 9(2).

29. Rudner, M. (1977). Education, development and change in Malaysia. Japanese Journal of Southeast Asian Studies, 15(1), 23-62.

30. Sendjaya, S., Pekerti, A., Härtel, C., Hirst, G., \& Butarbutar, I. (2016). Are authentic leaders always moral? The role of Machiavellianism in the relationship between authentic leadership and morality. Journal of Business Ethics, 133(1), 125-139.

31. Suhaimy, K. A. M. (2009). Pemikiran pembangunan berteraskan system nilai budaya: Kajian terhadap Pendekatan Dr. Mahathir Mohamad 1981-1986. Universiti Utara Malaysia: Ph.D. Thesis.

32. Sundaram, J. K., \& Cheek, A. S. (1988). The politics of Malaysia's Islamic resurgence. Third World Quarterly, 10(2), 843-868.

33. Suppiah, S. M., Ahmad, M. K., \& Gunasekaran, H. N. (2018). Mahathir's Leadership Communication: Exploring the Indians' Community Experience. Jurnal Komunikasi: Malaysian Journal of Communication, 34(2).

34. Taylor, R. D. (2003). The Malaysia experience: the multimedia super corridor. Information technology parks of the Asia Pacific: Lessons for the regional digital divide, 64-118.

35. van Houwelingen, G., van Dijke, M., \& De Cremer, D. (2015). Getting it done and getting it right: Leader disciplinary reactions to followers' moral transgressions are determined by construal level mindset. The Leadership Quarterly, 26(5), 878-891.

36. Welsh, B. (2005). Malaysia in 2004: Out of Mahathir's Shadow?. Asian Survey, 45(1), 153-160.

37. Williamson, T. (2002). Incorporating a Malaysian nation. Cultural Anthropology, 17(3), 401-430. 